\title{
Personnel- and action control in gazelle companies in Sweden
}

\author{
Ossi Pesämaa $^{1}$ (D)
}

Published online: 5 January 2017

(C) The Author(s) 2017. This article is published with open access at Springerlink.com

\begin{abstract}
Behavioral accounting theory questions the role of accounting and how accounting constructs can support other organizational activities. This paper examines whether personnel and action controls and the perception of current growth mediate meaningful support of innovative ideas (i.e., innovativeness) on future growth. While some literature has supported innovativeness as a spontaneous process, this paper examines whether innovative ideas are supported by formal behavioral controls on current and future growth. The paper further develops and finds support for the notion that future growth builds on the relative confidence of current growth. This paper uses exploratory factor analysis for construct validation and further tests mediation using structural equation modeling and the bootstrapping technique of indirect effects. The model testing is based on a survey conducted in Sweden with key informants from high-growth (i.e., gazelle) companies. A total of 150 usable responses were returned. The results may stimulate further research as they show that the predefined hypothesis has different direct and indirect roles in the building of future growth.
\end{abstract}

Keywords Management control · Organizational control · Personnel control · Action control $\cdot$ Gazelle $\cdot$ Growth

\section{Introduction}

A primary notion of any organization is implicitly or explicitly to define and pursue strategic and operational goals (Strauß and Zecher 2013). Typical strategic goals involve innovation and growth. Yet, an innovative company does not develop and pur-

\footnotetext{
$凶$ Ossi Pesämaa

ossi.pesamaa@1tu.se

1 Department of Accounting and Control, Luleå University of Technology, 97187 Luleå, Sweden
} 
sue new ideas to market in blindly (Wang and Tuttle 2014). Innovativeness is a risky (Davila 2000), difficult (Henri 2006), contextually dependent task (Hammad et al. 2013) that often involves several conflicting goals (Bedford 2015; Gaba and Joseph 2013; Mundy 2010). Furthermore, innovative companies seek processes that lead to meaningful outcomes that match existing products and fully exhibit potential for future growth (Bowen et al. 2010). Meeting and exceeding profitable market goals is the ultimate evidence of a meaningful innovation. In this context an increasing number of researchers acknowledge that employing sound management controls may balance processes that are only creative towards performance appraisals (Katsikea et al. 2015; Simons 2013).

To this end behavioral accounting theory (Colville 1981) suggests that, in situations of vague information from output measures, companies may consider employing formal behavioral controls (Kihn 2007). Such controls may signal not only control but the expectations that companies have of new ideas. In developing new products or expanding into new markets, information is often uncertain and imprecise and sometimes even based on wrong assumptions (Davila 2000; Henri 2006). Behavioral controls are a consequence of uncertain processes such as innovativeness and contribute to the company's ability to take desirable directions and avoid undesirable ones (Merchant and Stede 2007). The functionality of behavioral controls is thus to suggest knowledge and direction for unclear processes (Kraus et al. 2016; Ouchi 1977) and avoid uncertain innovative or growth outcomes (Martin-Rios 2015). Behavioral controls might not only be a process to define and follow up goals with metrics (i.e., controls) but might ultimately determine how resources are allocated and used in support (i.e., direction) of the organization's achievement of various objectives (Chenhall 2003). Consequently, what is measured will also be achieved, and the absence of concrete metrics hampers the likelihood of reaching tangible goals (Morris et al. 2006). Earlier empirical research has found that performance measures are often poorly developed and collected for other purposes (Virtanen et al. 2013). Taking into consideration that innovation and growth involve uncertainty (Sandelin 2008), carefully specified metrics may be needed to guide various scenarios and new directions (McGee et al. 1995). In addition, in practice it is known that the "creation and regeneration of products is expensive" (Pesämaa et al. 2013, p. 170) and that two-thirds of all innovations fail at an average cost of 15 million dollars (Girardi et al. 2005), it is plausible providing a financial argument to follow up such goals. Many of these cost driving issues are either organizational or strategic in nature, involving different individuals with different competencies who expect different information. Therefore, we propose that innovativeness along with behavioral controls may support current growth (Davila et al. 2004; Strauß and Zecher 2013), which further supports future growth.

Innovativeness is theoretically the notion that transforms new ideas into commercial ends that are useful only if someone is willing to pay for them (Henri 2006). This assumption ties innovativeness to growth. It is a tenet of business growth that reaching new customers and stimulating current customers to spend even more on core and related products of growth are key activities for innovative companies (Widener 2014). Furthermore, new ideas are only new until someone else offers the same or a similar product or service offering. Truly innovative companies therefore reiterate the same processes, differentiate existing processes, support meaningful action, and encourage 
innovative behavior (Pesämaa et al. 2013). However, supporting any innovative behavior may not be efficient and may incur a high cost. Efficient innovation and growth are intertwined in many ways. Once ideas reach a competitive market, the threat from existing products calls for other types of solutions. These commercial growth aspects have several implications for controls. A body of literature has emphasized the significance of growth for small (St-Jean et al. 2008) and particularly technology-oriented firms (Haustein et al. 2014). Many firms aspire to benefit rapidly, often through franchising, from their first-mover advantage (Michael 2003) or to grow faster and stay ahead of their competitors through strategic acquisitions. Such external growth strategies support fast expansion but also entail the focal firm undertaking considerable risk (Coy 2013). In a recent meta-analysis of 42 empirical studies accounting for 21,270 firms, Rosenbusch et al. (2011) found that external collaborative-based growth is more risky than internally oriented growth. Birch (1979) distinguished external growth from organic growth and referred to companies achieving the latter as gazelle companies. While the definitions of gazelle companies vary, there is a consensus that they are not micro companies but rather have a significant amount of employees and sales as well as a stable organic growth rate over a number of years.

Earlier studies have acknowledged that formal controls have an important role in the management of innovations (Bedford 2015). There has also been support for the suggestion that different strategies at different stages, such as growth strategies, may call for different controls (Bedford et al. 2016). Gazelle companies are important in this respect, as these have been claimed to be immune to failure (McKelvie and Wiklund 2010) and thus more likely to reach strategic goals. It is known that gazelle companies invest considerably in strategic activities (Tell 2012). For instance, they adopt an information strategy, which means that they acquire and transform information into commercialized products efficiently (Ryzhkova and Pesämaa 2015). Further studies on strategy and control have confirmed that these high-growth gazelle firms are only more innovative when the company is close to a technological frontier (Hölzl 2009). Their focus on strategy allows them to a larger extent to invest more time in identifying and selecting a mix of competencies and matching competencies (LopezGarcia and Puente 2012). Operationally, there is evidence that many of the founders of gazelle companies have relatively little business experience but strong strategic networking skills (Bee 2004). High-growth companies are efficient in transforming information from external stakeholders into specific goals (Achtenhagen et al. 2014; Parida et al. 2016). Consequently, there is greater awareness of individuals, teams, and networking strategies. Furthermore, studies have found that these companies have market and informational advantages (Zane 2011). Personal contacts and resources can therefore be matched and controlled to obtain meaningful commercial outcomes (Weber 2011). To sum up, the dominating theory suggests that high growth is achieved in companies that discuss innovation and growth in unstructured iterative processes (Bisbe and Malagueño 2015; Groesser and Jovy 2016). A contrasting perspective argues that growth is difficult to achieve, particularly through innovativeness, when there is a lack of control and structure (Epstein 2016). To this end, Tessier and Otley (2012) argued that the lever of control literature has tended to view control issues from a theoretical view and overlook their empirical validity. The absence of correspondence to empirical results and measures not synchronized to earlier studies has 
constrained the literature from developing a coherent body of research. Like much theoretical work with the aim of understanding ambiguity, this study contributes to improving the conceptual definitions and clarity. Since inappropriate or even wrong control measures consequently affect performance incongruencies, Tessier and Otley (2012) called for stronger coherence and testable transparent measures. A stream of research has also started to recognize how formal controls can support the management of goals that otherwise would be at odds (Bedford 2015; Mundy 2010). Controls may support companies in managing these from one point and offer meaningful feedback. This study contributes to bridging the theoretical gap on how growing companies and innovativeness occur and whether management controls may help to bridge the gap between innovativeness and growth. As both innovativeness and growth conceptually involve uncertainty, formal control systems may decrease uncertainty through feedback. In addition, this suggests separating current and future growth as one avenue to seek more forward-looking perspectives. The benefit of many longitudinal studies is their comprehensive implications for pinpointing causal effects, but those effects are often rather retrospective and backward looking instead of forward looking (Bourne 2014; Chen 2008). To this end this paper may also inspire forecasting controls.

Innovation and growth represent processes that are often less controlled and have a vision that is consistent with future objectives; however, few studies have addressed this gap. This paper therefore examines how and to what extent gazelle companies' management control affects their current growth perception, which further breeds future growth. To achieve this, the paper merges the growth literature with the notion of management control by asking: Do management control and current growth mediate innovativeness on future growth? As such, the paper also intends to stimulate future studies to examine the role of management control in relation to innovativeness. To address these issues, the study proposes and tests a model empirically tested on 150 gazelle companies in the Swedish context. The data is analyzed using a structural equation model. The paper aims to contribute to the literature on behavioral theories, management, and organizational control.

\section{Behavioral theory, performance feedback, and performance evaluation}

Performance and growth are never a straight forward process (Jänkälä and Silvola 2012), and conflicting empirical findings exist regarding what constitutes growth (Kennedy and Affleck-Graves 2001; Laitinen 2011; Maiga and Jacobs 2008). Many of the variations in the existing studies originate from differences in the measurement of growth (Laitinen 2014) and the context (Alsharari et al. 2015). The growth literature is therefore a mix of a variety of assumptions that originate from different fields of research (Lounsbury and Beckman 2015). Growth is one aspect of performance (Ittner and Larcker 1998). Behavioral theories involve the ways in which a company's develop plans, actions, growth outcomes and influence their likelihood of success or failure. Management control is a limb of behavior theory. In management control it is suggested that concrete motivation schemes and orientation through financial metrics contribute to goal attainment (Kolk and Schokker 
2016). The goal and results orientation is thus bound to management routines and practices. Nevertheless, when companies reach their desired outcomes, they reiterate the same actions, and when companies are unable to meet their desired outcomes, they revise their plans and actions and suggest new ones (Kim et al. 2011). This retesting approach is based on the assumption of behavioral theory (Colville 1981). Behavioral theory is a meta-theory encompassing various kinds of behaviors. The objective approach to verifying evidence appeals to micro theories and here conceptually based performance-related theories (Ijiri 1975). For instance, these processes are at the heart of what some researchers have synonymously referred to as performance feedback theory (Greve 2003a,b) or performance evaluation (Ijiri 1975). Hitherto, performance feedback theory rested on behavioral theory, making general assumptions concerning how decisions are reached (Cyert and March 1963).

While feedback takes place after goal attainment, the precursor to goal attainment involves controls (Laitinen 2014) and past experience (Greve 2003a, b). Performance feedback strongly claims that individuals behave according to the expected appraisals (Lounsbury and Beckman 2015). It further assumes that evaluations of past performance affect future performance (Bowen et al. 2010; Greve 2003a, b) and that future performance is an effect of intentions (Luft and Shields 2001), future aspirations (Greve 2003a,b), the ability to convert, transform, and achieve performance goals (Lau 2015), and strength in innovative processes (Bowen et al. 2010; Rosenbusch et al. 2011). Earlier research has shown that a lack of feedback, which is the ultimate function of formal controls, leads to overconfidence (Hunt 1995) but combined with experience, may lead to less overconfidence (Hyatt and Taylor 2008). In large organizations managers can allocate a significant amount of time to refining the controls for adequate feedback (Burney and Widener 2013) and appraisals (Miller and Cockrell 2015). Controls thus support processes that bind activities to controls and adequate allocation of these.

Behavioral theory is the precursor to the performance feedback theory and explains how organizations respond and adapt to the environment. Behavioral theory introduces the concept of specified objectives to be fulfilled and from the point when feedback is given on the performance. Such assessment is based on whether the performance is sufficient in terms of the organization's ambition and aspiration. This assessment leads to processes involving a constant search for achievements, which provides feedback and thereby leads to changes in organizations (Greve 2003a).

\subsection{Behavioral theories in accounting and management control}

Performance evaluation (Ijiri 1975) is closely linked to behavioral accounting theories (Kihn 2007), distinguishing assumptions about what people are and how the use of information may be applied to reach specific goals (Colville 1981). Behavioral accounting is critical, as it questions the role of accounting and its goal in terms of other organizational activities (Balachandran 1985). This is important, because any performance measure initiated by managers implies a direction towards an organizational activity (Colville 1981). 
Herewith, formal management control refers to the "process by which managers assure that resources are obtained and used effectively and efficiently in the accomplishment of the organization's objectives" (Anthony 1965, p. 17). Strauß and Zecher (2013) defined management control as the type of planning that synchronizes strategic (i.e., long-term) and operational (i.e., short-term maintenance and day-to-day routines) control. Furthermore, management control involves tight formal output controls in combination with interactive, open, flexible diagnostics of these controls (Simons 1987, 1994). Davila (2000) extended these diagnostics to close controls and specific details of products, design, and customers. Chenhall (2003) extended management control by emphasizing the context and stated that controls (i.e., measurements) involve control (i.e., direction). Flamholz, Das, and Tsui (1985, p. 38) defined organizational control (i.e., individual in the organization) as a "process of influencing the behavior of people as members of a formal organization." They viewed behavioral controls as those systems and mechanisms that include processes and techniques embedded in a formal organizational context and are designed to increase the probability that individuals will attain the organizational goals accordingly (Chenhall 2003; Flamholtz et al. 1985). Management (Malmi and Brown 2008) and organizational control (Flamholtz et al. 1985) is thus a theory of performance goals and, specifically, how performance goals can be reached (Ghalayini and Noble 1996; Guenther 2013; Kolk and Schokker 2016). While an organizational goal is more tuned towards accomplishment of organizational goals, management control seems conceptually to veer more towards the achievement of overall strategic goals. Strategic goals, representing the principal action of managers, are here assumed to precede organizational goals (De Harlez and Malagueño 2015). The theoretical notion is that strategic goals include organizational goals and are therefore hierarchically overarching to organizational goals, such as growth. Management control is thus logically a principal goal to achieve the overall performance goals. Management control further assumes that organizing activities into precise goals may enhance independence and the likelihood of reaching the overarching strategic goals (Kihn 2010), such as growth.

As goals can seldom be met perfectly, performance is the relative outcome of performance goals (Greve 2003a, b). It is tempting to consider management and organizational control with a deterministic view of future performance (Adams et al. 1993). A deterministic view considers every unit of goals as input into a unit of future performance. The logic of such a deterministic view of management and organizational control is that goals are set to be achieved (Malmi and Brown 2008). However, the achievement of goals often falls short of or exceeds that predicted. The conceptualizations of unfulfilled or exceeded goals are therefore negative or positive deviations (De Harlez and Malagueño 2015; Ven and Polley 1992). These deviations are often used subsequently in interactive discussion and diagnostics to analyze and explain the reasons for this difference. The idea is thus to search iteratively for an explanation for this difference. One step forwards may require one step backwards. Such follow-up is often considered important for strategic development (Rosenbusch et al. 2011).

Performance evaluation is therefore a vivid process (Bai et al. 2010; Ittner and Larcker 1998). Through the use of goals it becomes a concrete process also in small organizations. Performance and performance goals can reflect organic growth (Geroski 
et al. 1997), employees, sales, profits (Ittner and Larcker 1998), and the number of new products (Ryzhkova and Pesämaa 2015) and is often a result of the relative success of operations in specific markets (Ittner and Larcker 2003), industries (Janssen et al. 2011), and companies' ability to position their products in the market (Cosenz and Noto 2015). The latter process involves both refining current products and developing new products towards commercial ends (Haustein et al. 2014). It is often referred to as innovativeness, while the ultimate outcome in the market is the innovation (Janssen et al. 2011). Any of these performance aspirations ultimately represent goals.

Haustein et al. (2014) found in their review that innovative companies are negatively related to results and action control but positively related to personnel control. Their inference was thus that innovative companies are determined by more creative and cultural leadership processes (Haustein et al. 2014) than the strict administrative manuals sometimes found in action control (Abernethy and Brownell 1999). Furthermore, their study expects that innovative companies tailor their performance measures to obtain venture and public funding. Moreover, innovative ideas are often intertwined with growth aspects. Innovative companies with attractive products (including services) are also keen to find a broad exit for these products.

Operational processes that involve the industry, market, and products are intertwined in many ways (Gardner et al. 2000). Not only are product life cycles shorter and more dynamic because of industry or market logics (Werker 2003) but also current products are replaced at a faster pace because of the technology in a certain market or industry (Palacios Fenech and Tellis 2015). Growth is furthermore explained by industries and markets in which product standards, technology, intelligence, branding, or collusion enable a few actors to develop oligopolies while constraining others by strong entry barriers (Caves and Porter 1977). Research and practice are therefore constantly working on the edge to identify new techniques to know more, forecast better, and ultimately control these processes more effectively (Eccles and Pyburn 1992).

While success and thus future success can be explained by past success and thus past behavior (Audia et al. 2000; Bowen et al. 2010), many firms invest heavily to identify possible future scenarios (Sandelin 2008). Management control is one notion that suggests metrics to follow growth and planning (Janssen et al. 2011).

\section{Development of hypotheses}

\subsection{Innovativeness in personnel and action controls}

Innovativeness is tied to performance (Gurd and Helliar 2016) and often explicit expectations of growth. Innovative outcomes are often suggested as a means to sustain and grow in a particular market (Pesämaa et al. 2013). As innovation conceptually originates from the Latin term innovatio, which means to renew or to make changes to the existing regime (Carayannis and Gonzalez 2003), such changes initiate a change in the established routines and practices. Any change needs the allocation or reallocation of resources (Ven 1986) and thus also new measures and management control systems (Davila 2000). Management control systems may support the way in which creativity, renewal, and openness towards new ideas are directed (Henri 2006) and therefore also 
affect future growth. Efficient (or a lack of efficient) and successful innovativeness therefore affects performance (Bowen et al. 2010; Rosenbusch et al. 2011).

At the bottom line, management control depends on the extent to which individuals are involved in reaching shared strategic and operational goals (Othman and Said 2007). Managers often implement such strategies and decide how resources are allocated. Some processes are more innovative than others and may be undergoing continual change, requiring constant decisions from a manager. A manager needs to decide which routines, policies, and strategies to adopt and how to follow up new ideas and to align these with the current platforms through established management control systems (Chen 2008). Some companies may thus, through established management control systems, have the stability to pass constantly through changes successfully, whereas others may lack this. Yet, although successful companies may have procedures (i.e., format, routines, and management practices) to take a company through changes, they may also encounter difficulties outside these established practices (Ven 1986). Such interaction may place standards on one side and newness on the other, thus creating tension. Simons $(1987,1994)$ referred to this interactive process as "tension," wherein creative innovative ideas are relatively at odds with goal attainment. When ideas are at odds controls inspire evaluation and direction for decisions. Furthermore, not all new ideas are innovative, as innovation includes both newness to a market and market exit.

In addition to financial goals, an organization typically suggests non-financial goals (Kotlar et al. 2014). Personnel control includes processes to involve, influence, motivate, and inspire, and it also considers personnel goals (Kleine and Weißenberger 2014). Nevertheless, such personnel goals develop not in isolation but through followup action controls (Kleine and Weißenberger 2014) during an operation rather than afterwards (Helsen et al. 2016). Many of these are forward looking. Results control is an outcome-based control that is often used to follow up achieved results. Both personnel and action controls, however, refer to behavioral controls (Merchant and Stede 2007). Action control is a typical behavioral control, which is active during an operation (i.e., not only afterwards) and seeks to ensure desirable behavior (Kihn 2008). Personnel and action controls are here predefined by innovativeness as organizational goals, as these can hold the managers to account for their actions (Matsuo 2009). Procedures, routines, and other follow-up processes can ensure that significant controls are considered carefully (Merchant and Stede 2007).

In the context of innovativeness, wild-eyed ideas are not developed fruitfully unless they have been questioned on a sound basis (Wang and Tuttle 2014). Innovativeness may thus affect controls and future performance (Matsuo 2009; Simons 2013). Innovative processes may influence not only innovative outcomes but processes and strategic routines that strengthen the competitive position (Bowen et al. 2010). As innovative processes introduce uncertainty into organizations (Broadbent et al. 2008; Soin and Collier 2013), formal controls, even with a low degree of structure (Heinicke et al. 2016; Tessier and Otley 2012), question the relevance and validity of such ideas, thus limiting or avoiding wrong strategic risks and uncertainties (Bedford 2015; Curtis and Sweeney 2016). When the growth potential of a company is low, it may lower the strategic innovative efforts, while companies with a successful past may stimulate efforts through the same controls that offer confidence (Pesämaa et al. 2013). Current 
and expected future growth may thus be conditioned by the way in which controls intervene in the effects of innovativeness on the future. Therefore, the logic is that controls depend on a meaningful innovative process with direction towards the future. Hence:

H1 There is a positive relationship between innovativeness and personnel control.

H2 There is a positive relationship between innovativeness and action control.

\subsection{Management control and current growth}

At the firm level, growth reflects productivity and the number of goods and services produced (Sandelin 2008). Earlier research has claimed that current growth depends on management accounting systems (Davila and Foster 2005). Controls and the ability to interpret and convert metrics into feedback are a leadership and managerial issue (Gurd and Helliar 2016). Detailed knowledge from these systems supports growth opportunities, as the details of new markets and/or new industries may differ significantly (Bourne 2014; Lavia López and Hiebl 2014). The direction of growth is thus determined by the perceptual situational analysis on which the management accounting system rests (Davila and Foster 2005). Poor personnel or action control may also engender poor support for growth. Studies have also indicated that changes in the environment can make earlier strategies ineffective (Huang et al. 2015), which is why better controls may generate more expected results. Furthermore, both personnel and action controls per se stress desirable actions (Kihn 2007, 2008, 2010).

It may seem contrasting that current growth depends on controls, yet firms that are more sensitive and reflective on their current growth may also be more likely to achieve future growth (Simons 2013). Formal personnel and behavioral action controls build positions towards specific tasks related to the desired current and future growth (Bourne 2014; Bowen et al. 2010; Chen 2008; Kihn 2008).

Therefore:

H3 There is a positive relationship between personnel control and current growth.

H4 There is a positive relationship between action control and current growth.

\subsection{Management control and future growth}

Personnel control is herein theoretically defined as organizational control that influences the individual likelihood of attaining the overall organizational goals (Flamholtz et al. 1985). Action control is defined in this study as management control that follows up plans to meet the overall strategic (including organizational) goals (Kleine and Weißenberger 2014). It is further assumed that both organizational personnel control and organizational strategic control evolve as well as affecting performance.

However, as many companies are constrained by limited resources (Henri 2006), including innovative ones, and adopt certain strategies to control them, resources may be allocated accordingly. Earlier studies have found that "performance noise" that reflects imprecise control of, for instance, contracting affect performance outcomes significantly (Bai et al. 2010). Management and organizational control can therefore be seen as a mediating variable that either releases opportunities or constrains those who 


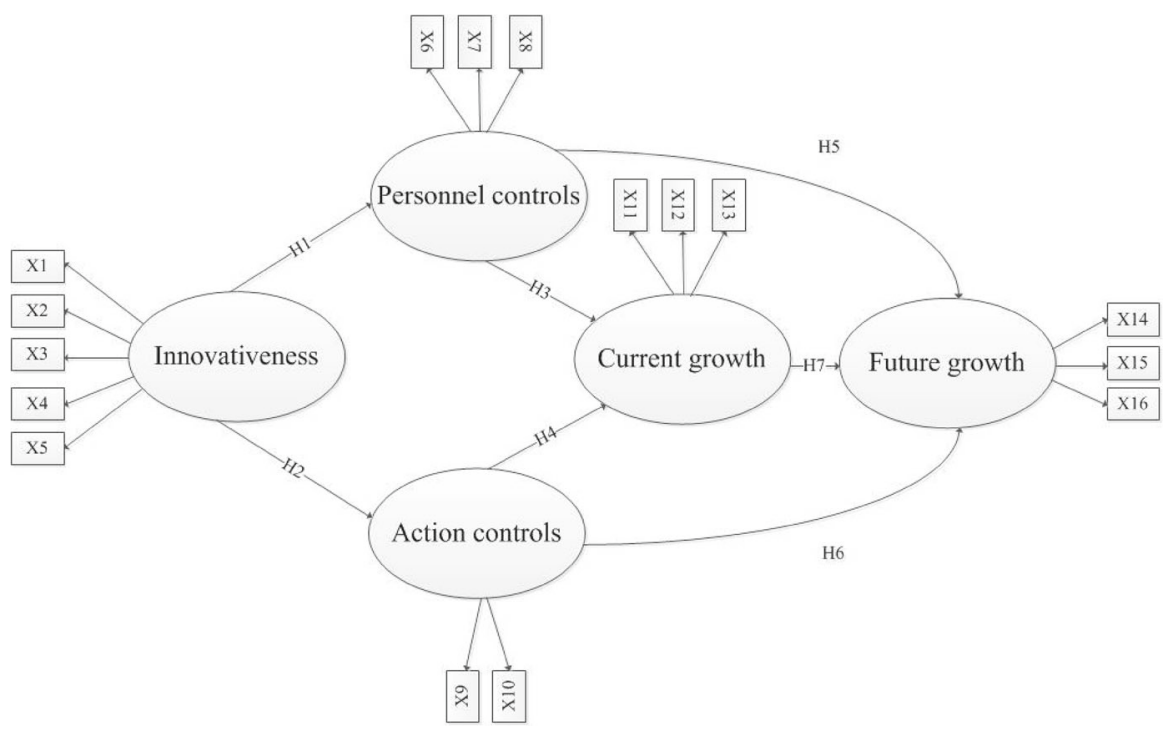

Fig. 1 Theoretical model

will not match the company goals (Kleine and Weißenberger 2014). Davila et al. (2004) suggested that innovative growth-oriented firms use metrics and involve employees (particularly managers) to attain future objectives (Fig. 1).

Growth is associated with uncertainty (Laitinen 2011). As growth is ambitious and lacking in reference points (Shinkle 2012), it motivates non-financial control that follows up the perceived uncertainty (Speklé and Verbeeten 2014). New growth means new challenges, a change of resource allocation, and new means to control expansion. Therefore, it is herein suggested that past experience, past performance, and management control may lower uncertainty. Past growth experiences also logically reflect current management control systems. Growth is a divisive construct, as it may increase rapidly and diminish over time. The notion of uncertainty therefore suggests that growth is supported by management control (Banker and Hughes 1994; Katsikea et al. 2005; Kennedy and Affleck-Graves 2001; Laitinen 2014; Langfield-Smith 2006).

Therefore:

H5 There is a positive relationship between personnel control and future growth. H6 There is a positive relationship between action control and future growth.

\subsection{Current growth and future growth}

There is no such evidence that past growth will by all means engender new growth. Many have postulated that current goals are reference points for future goals and current growth for future growth (Shinkle 2012). It is also known that organizations invest heavily to form strategic growth goals and to meet these goals. Kim et al. (2011) found that, when such aggressive growth strategies are disrupted or fail, they affect behavior and some organizations' collective actions take on more risky strategies. Henrekson 
and Johansson (2010) described growth as not only an achievement that enables greater economic gains for the manager but also as providing information about the strength of the opportunities. However, performance and future growth are largely based on past performance (Miller and Chen 1994). There is strong evidence that the same perceptions, shared behavior, and actions that were present in forming past growth will also take place in the formation of future growth (Audia et al. 2000). Even though such perceptions about the current growth situation are wrong, based on wrong premises, there is evidence that past growth affects the ways in which the individuals within an organization will think and act in the future (Audia et al. 2000; Bandura 1997). Performance feedback theory also claims that negative conditions are typically alleviated in favor of past conditions (Greve 2003a). This notion of confidence is strongly rooted in behavioral theory and the idea that experience encourages leaders to interpret conditions similarly, especially if the past was a success (Lounsbury and Beckman 2015). Perceptions based on experience (Weber 2011) that help to form the current state are therefore significant for future performance (Audia et al. 2000). Mahama (2006) posited that actions are not developed in isolation but that past current actions are expected to affect future actions. Any adoptions of new activities, such as new programs, new practices, new projects, or new directions, are therefore based on past or current activities. Yet ideas, herein also including modifications of current ideas, are new as long as they are perceived as new by those involved in accepting the new practices (Ven 1986). Speklé and Verbeeten (2014) argued that the type or conditions of goals and goal outcomes affect performance. When goals are unambiguous and known, performance can be measured, diagnosed, and followed up with strategized operations (Cavalluzzo and Ittner 2004). As innovation and growth per se involve uncertainty and risk, their outcomes are more likely to be followed up by responses to growth or performance. Innovative product strategies are directly echoed in firm outcomes and growth. When the growth strategies adopted mean that the focal company experiences poor or no growth, the position is the status quo or significant growth strategies (Bandura 1997). On the contrary, in situations when companies experience growth, they are less motivated to change their future growth strategies (Kim et al. 2011; Chen 2008). Positive growth breeds future growth and therefore is also more forward looking than backward looking. Therefore:

H7 There is a positive relationship between the perception of current growth and the future growth.

\section{Method}

\subsection{Survey design, administration, and sample}

This study undertakes an empirical approach (Wold 1989), testing the relationships between the outcome and the antecedents of management control within the scope of growth. The model is tested on a sample of gazelle companies in Sweden in spring 2015. Data were drawn from a total sample of 999 gazelle companies selected by the biggest business magazine in Sweden. While more companies would fit within this definition of gazelle companies, we used a preselected list of companies published in 
the magazine. The organizational names were converted into organizational numbers and then further converted into key informants within the organization. In 2014 there were a total of 999 gazelle companies. These companies have at least 10 employees, a turnover of 10 million SEK (approx. 1.2 MUSD), and a growth rate of at least $30 \%$ for the past 3 years and are based on organic growth (i.e., not external growth or franchising). These companies were thus drawn from all industries. A questionnaire was distributed to all the companies, achieving a response rate of $15 \%$, which amounts to 150 responses. A non-response bias test was performed (Armstrong and Overton 1977) by comparing early and late responses.

\subsection{Variable measurement}

The main variables are measured as constructs and are synonymously referred to as factors with multiple indicators. These indicators are measured by a correlation coefficient in Table 1 and a factor loading $(\lambda)$ in Table 2. Every construct is labeled to represent an underlying theoretical dimension. As such, a multi-item factor is theoretically purported to measure one dimension; it also meets the criteria that the sample is homogeneous and that there is multicollinearity (Hair et al. 2010). Table 1 reports all the correlations at the variable level. The correlation matrix (Table 1) thus enables researchers to replicate this study using correlations as an input matrix and reports whether there is the support of multicollinearity within each construct (see the coefficients marked in bold in Table 1). Furthermore, Table 1 reports that all the correlations are not only robust but stronger within each construct than between the constructs.

The measurement of innovativeness is based on a five-item definition. Earlier studies have emphasized a metrics-based control for innovative ideas (Davila 2000; Davila et al. 2004; Janssen et al. 2011). Davila et al. (2004) defined innovative processes as not only creative ideas but also useful if they match a commercial need. Herein innovativeness is defined as an organizational trait (i.e., ongoing group behavior) of continuous risk and creative planning. The measurement reflects risk, idea implementation, creativity, the importance of innovative development, and continuity. As suggested by Hair et al. (2010), a measure should have substantial and balanced factor loadings $(\lambda>0.7)$ and a Cronbach alpha $(\alpha)$ that is substantial $(\alpha>0.70)$. It is worth noting that the second item in innovativeness is marginally low $(\lambda=0.58)$, and this is important to consider for future studies.

The third section in the survey instrument measures personnel and action control. Kleine and Weißenberger (2014) included fifteen items to measure three dimensions of control, namely personnel, action, and cultural control. Their study received strong support for all the dimensions, including strong reliability and validity. This paper to some extent uses different definitions of personnel and action control. Personnel control here reflects perceived behavioral influence, opinions, and goals. This measure of personnel control reports satisfactory levels of convergent validity $(\lambda>0.7)$ and reliability $(\alpha>0.70)$. Secondly, action control is reflected by control as goals' accomplishment and follow-ups to negative deviations. This measure also meets the criteria of convergent validity $(\lambda>0.7)$ and reliability, here measured by inter-item correlation, as the measure itself has fewer than three variables $(r=0.80)$. 


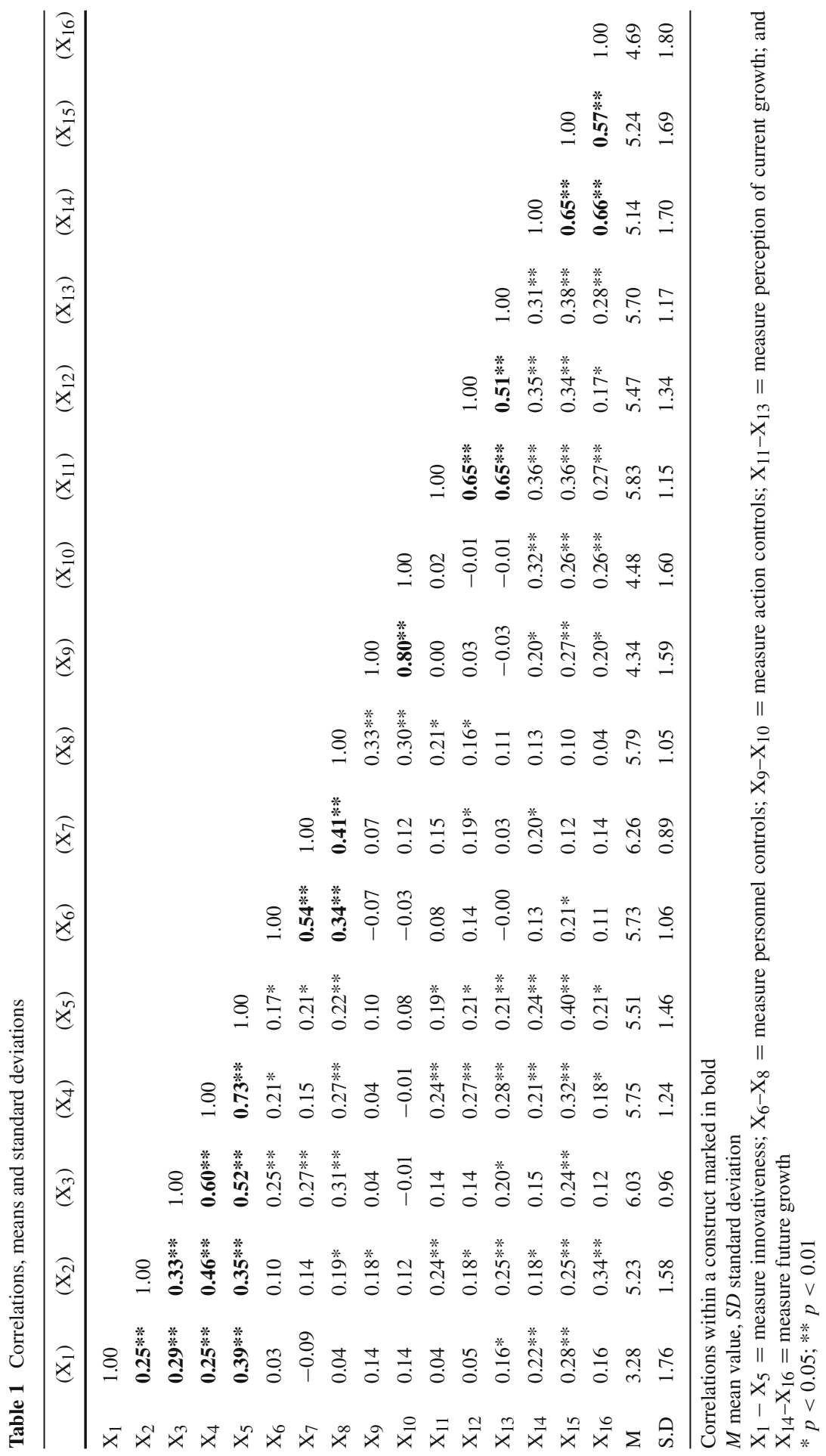


Table 2 Exploratory factor analysis and reliabilities $(\mathrm{N}=150)$

\begin{tabular}{|c|c|c|c|c|c|c|}
\hline Item & Factor 1 & Factor 2 & Factor 3 & Factor 4 & Factor 5 & Reliability \\
\hline $\begin{array}{l}\text { INN } \lambda 1 \text { : Promote and take } \\
\text { on risk to generate } \\
\text { future profit }\end{array}$ & $\lambda=0.60$ & $\lambda=0.16$ & $\lambda=-0.01$ & $\lambda=-0.18$ & $\lambda=0.12$ & $\alpha=0.74$ \\
\hline $\begin{array}{l}\text { INN } \lambda 2 \text { : Implement ideas } \\
\text { we did not plan for }\end{array}$ & $\lambda=0.56$ & $\lambda=0.07$ & $\lambda=0.12$ & $\lambda=0.00$ & $\lambda=0.20$ & \\
\hline INN $\lambda 3$ : Support creativity & $\lambda=0.73$ & $\lambda=0.00$ & $\lambda=0.12$ & $\lambda=0.30$ & $\lambda=-0.07$ & \\
\hline $\begin{array}{l}\text { INN } \lambda 4 \text { : Develop } \\
\text { innovative } \\
\text { products/services }\end{array}$ & $\lambda=0.81$ & $\lambda=0.08$ & $\lambda=0.14$ & $\lambda=0.16$ & $\lambda=-0.08$ & \\
\hline $\begin{array}{l}\text { INN } \lambda 5 \text { : Constantly } \\
\text { develop new products }\end{array}$ & $\lambda=0.77$ & $\lambda=0.26$ & $\lambda=0.03$ & $\lambda=0.11$ & $\lambda=0.00$ & \\
\hline $\begin{array}{l}\text { PC } 1 \text { 1: Support influence } \\
\text { over your own work }\end{array}$ & $\lambda=0.12$ & $\lambda=0.15$ & $\lambda=0.04$ & $\lambda=0.82$ & $\lambda=-0.15$ & $\alpha=0.76$ \\
\hline $\begin{array}{l}\text { PC } \lambda 2 \text { : Listen to personal } \\
\text { opinions about work }\end{array}$ & $\lambda=0.01$ & $\lambda=0.13$ & $\lambda=0.04$ & $\lambda=0.87$ & $\lambda=0.03$ & \\
\hline $\begin{array}{l}\text { PC } \lambda 3 \text { : Make sure specific } \\
\text { work-related goals are } \\
\text { met }\end{array}$ & $\lambda=0.18$ & $\lambda=-0.08$ & $\lambda=0.14$ & $\lambda=0.71$ & $\lambda=0.40$ & \\
\hline $\begin{array}{l}\text { TC } \lambda 4 \text { : Control goals are } \\
\text { accomplished }\end{array}$ & $\lambda=0.09$ & $\lambda=0.16$ & $\lambda=-0.03$ & $\lambda=0.02$ & $\lambda=0.92$ & $\mathbf{r}=\mathbf{0 . 8 0}$ \\
\hline $\begin{array}{l}\text { TC } \lambda 5 \text { : Ask for } \\
\text { explanation if actions } \\
\text { are not accomplished }\end{array}$ & $\lambda=0.02$ & $\lambda=0.27$ & $\lambda=-0.06$ & $\lambda=0.04$ & $\lambda=0.90$ & \\
\hline $\begin{array}{l}\mathrm{CG} \lambda 1 \text { : Opportunities in } \\
\text { current markets }\end{array}$ & $\lambda=0.04$ & $\lambda=0.14$ & $\lambda=0.90$ & $\lambda=0.11$ & $\lambda=0.00$ & $\alpha=\mathbf{0 . 8 0}$ \\
\hline $\begin{array}{l}\text { CG } \lambda 2 \text { : Opportunities } \\
\text { based on current } \\
\text { products }\end{array}$ & $\lambda=0.08$ & $\lambda=0.22$ & $\lambda=0.73$ & $\lambda=0.17$ & $\lambda=-0.04$ & \\
\hline $\begin{array}{l}\text { CG } \lambda 3 \text { : Significant growth } \\
\text { potential in current } \\
\text { markets }\end{array}$ & $\lambda=0.20$ & $\lambda=0.09$ & $\lambda=0.84$ & $\lambda=-0.09$ & $\lambda=-0.02$ & \\
\hline $\begin{array}{l}\text { FG } \lambda 1 \text { : Opportunities in } \\
\text { new markets }\end{array}$ & $\lambda=0.12$ & $\lambda=0.85$ & $\lambda=0.19$ & $\lambda=0.14$ & $\lambda=0.17$ & $\alpha=\mathbf{0 . 8 1}$ \\
\hline $\begin{array}{l}\text { FG } 2 \text { 2: Opportunities } \\
\text { based on new products }\end{array}$ & $\lambda=0.28$ & $\lambda=0.79$ & $\lambda=0.21$ & $\lambda=0.09$ & $\lambda=0.17$ & \\
\hline $\begin{array}{l}\text { FG } \lambda 3 \text { : Significant growth } \\
\text { potential in new } \\
\text { markets }\end{array}$ & $\lambda=0.13$ & $\lambda=0.84$ & $\lambda=0.11$ & $\lambda=0.04$ & $\lambda=0.13$ & \\
\hline
\end{tabular}

Extraction method: principal component analysis. Rotation method: varimax with Kaiser normalization. Rotation converged in five iterations. Eigenvalue: 1.13. Variance explained $71.32 \%$

Loadings associated with each factor are in bold

There is an ongoing debate regarding the validity of either objective or subjective performance measures (Bedford 2015). Venkatraman and Ramanujam (1987) emphasized that both subjective and objective measures have their own limitations. In this study we use a multi-item subjective measure reflecting opportunities in markets, the 
likelihood of success with new products, and growth (Widener 2007). While Bedford (2015) integrated current and future growth and highlighted some issues with marginally low factor loadings in this measure, this paper separates this dimension into current and future growth. Our operational definition of performance is thus two dimensional, reflecting (1) opportunities in current markets ${ }^{1 \mathrm{a}}$, the likelihood of success with current products ${ }^{1 \mathrm{~b}}$ and growth potential in current markets ${ }^{1 \mathrm{a}}$, as well as (2) opportunities in new markets $^{2 \mathrm{a}}$, the likelihood of success with new products ${ }^{2 \mathrm{~b}}$, and growth potential in new markets ${ }^{2 \mathrm{c}}$. These measures thus separate past and future ideas of growth. Our first dimension, which is current growth, has substantial factor loadings (see Table 2) varying between 0.73 and 0.90 , indicating strong convergent validity. All the cross-loadings (Table 2) are also below 0.30, indicating support for the suggestion that the "current" is differentiated from the "future." In addition, current growth exceeds the recommended reliability cut-off (Hair et al. 2010), with a Cronbach alpha $>0.70$ (Table $2 \alpha=0.80$ ). Similarly, future growth is well balanced (Table 2: factor loadings $0.79-0.85$; cross-loadings $<0.30$ and $\alpha=0.81$ ).

\section{Results of the structural model}

After establishing that each variable converges with a single-factor structure provided by an exploratory factor analysis, we tested the model using the theory-testing structural equation modeling approach (Bagozzi and Yi 2012). Our model was depicted and tested as a full structural equation model. The model includes one independent variable, three mediating ones, and one dependent variable. The structural model involves seven hypotheses, in which theoretical arguments support substantial relationships between current and expected future growth. The earlier theory is divisive, but it is herein also proposed that innovativeness and personnel and action controls support this dependent construct. The findings indicated that the structural model had an acceptable fit (goodness-of-fit: $\chi^{2}=177.552 ; d f=97 ; p$ value $=.000 ; \chi^{2} / d f=1.84 ; \mathrm{CFI}=.92$; RMSEA $=.07$; SRMR $=.08$ ). The proposed model explained $36 \%$ of the variance in future growth and $6 \%$ of the current growth. Innovativeness as a single antecedent to personnel and action control explained between 1 and $13 \%$ of the variance. Further diagnostics reported that relatively little is supported by these antecedents but much of the variance is explained by the current growth of future growth.

First, as hypothesized, innovativeness (H1) supports personnel control (Table 3; Model 1: H1: $\beta=0.36, p<0.01)$. However, innovativeness (H2) does not support action control (Table 3; Model 1: H2: $\beta=0.08, p>0.05$ ). Furthermore, we postulated and found support that personnel control (H3) strongly supports current growth (Table 3; Model 1: H3: $\beta=0.25, p<0.05$ ), while action control has a negative insignificant impact on current growth (Table 3; Model 1: H4: $\beta=-0.04, p>0.05$ ). The final step hypothesized that personnel and action controls and current growth affect future growth. Here, our findings confirmed that personnel control (H5) marginally supports future growth (Table 3; Model 1: H5: $\beta=0.18, p<0.05$ ). While action control reported no or a negative relationship with current growth, as expected (H6), it strongly affected future growth (Table 3; Model 1: H6: $\beta=0.41, p<0.005$ ). If personnel growth representing more creative processes is intertwined with future 


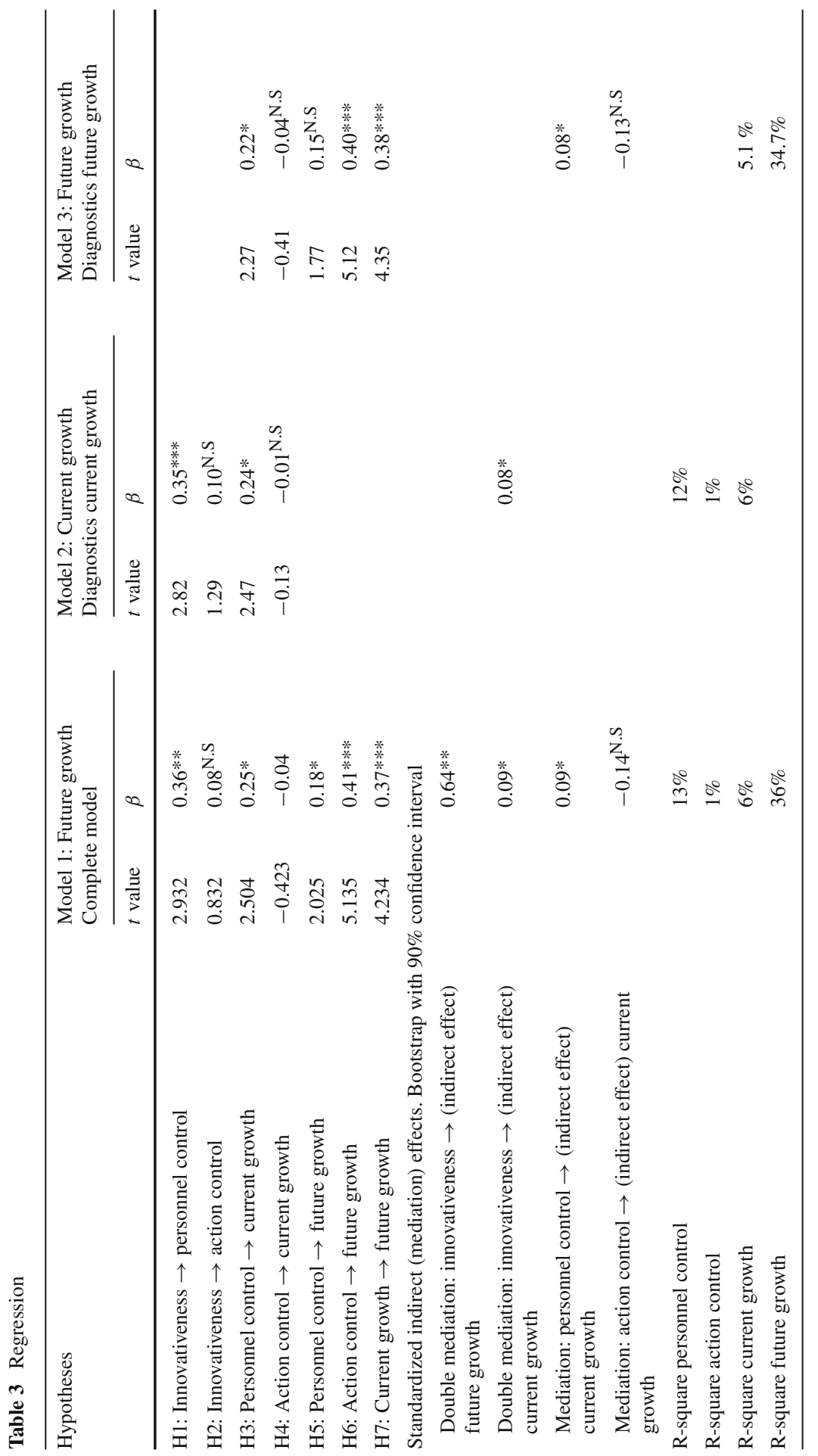




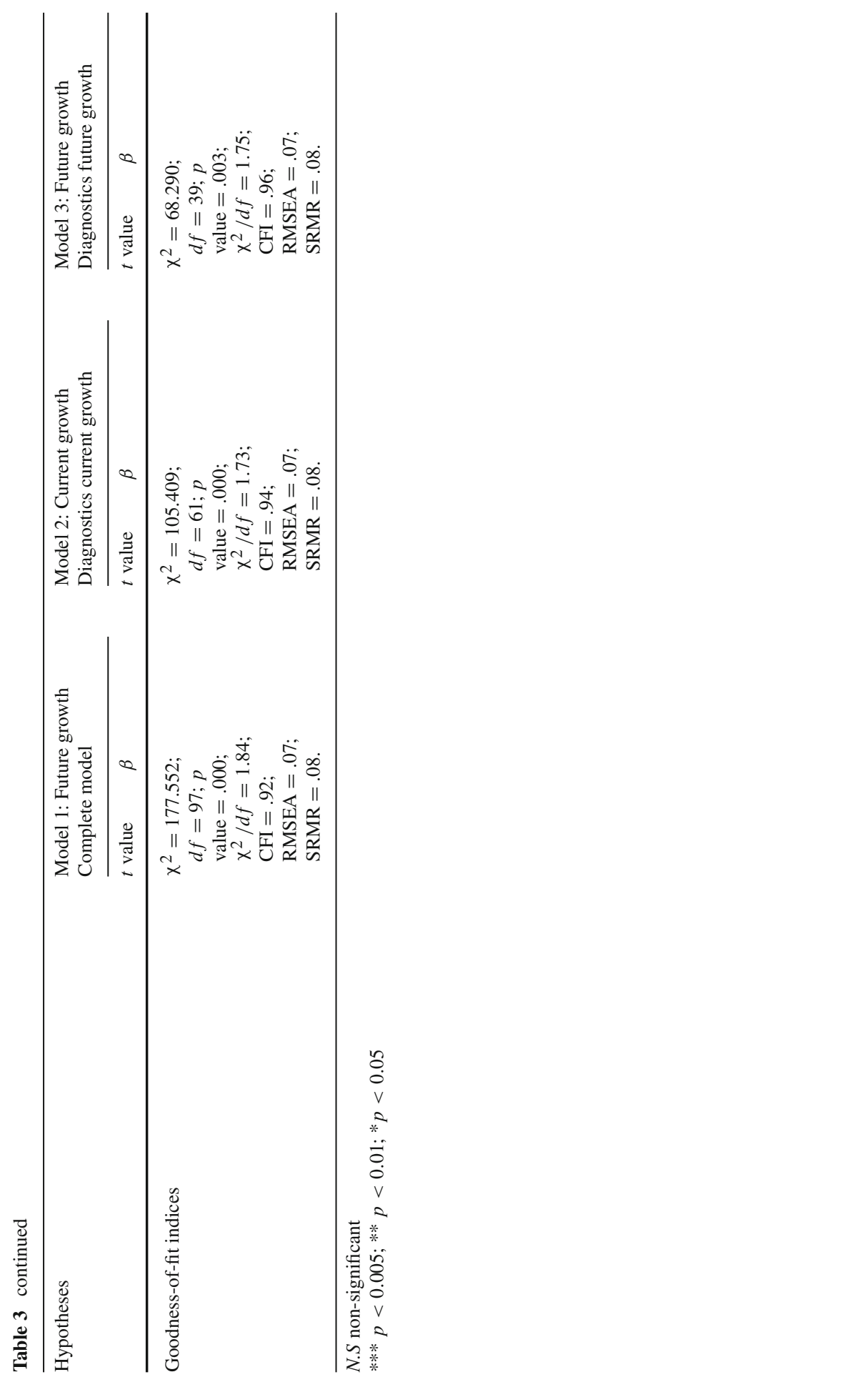


innovativeness, action control seems to be more intertwined with growth orientation. Finally it was proposed and here supported that current growth $(\mathrm{H} 7)$ significantly affects future growth (Table 3; Model 1: H6: $\beta=0.37, p<0.005$ ).

Furthermore, we separated current growth from future growth to test the robustness of the supported effects. Leaving out future growth, Model 2 in Table 3 supports the assertion that innovativeness is robust in affecting growth and that the mediation (indirect effect) only changes marginally. Similarly, Model 3 in Table 3, leaving out innovativeness, coin out that the expected mediating (indirect) effects all come from personnel control, while action control all comes from personnel control when the mediating effects from action control are negative and insignificant. Yet these diagnostics reveal that action control remains robust with a direct effect on future growth.

\section{Discussion}

This paper examined the relationship between innovativeness and growth. The fundamental notion of the paper is that innovation cannot be directly related to growth, as earlier research has indicated several counter arguments and critiques against this (Bowen et al. 2010; Rosenbusch et al. 2011). However, the extant research has started to recognize that controls can support innovativeness and growth, particularly when many goals are at odds (Bedford 2015; Mundy 2010). Innovativeness and growth aspirations are social in nature, and controls have also been argued to bond social processes through tangible feedback systems (Heinicke et al. 2016; Tessier and Otley 2012). As innovativeness and growth are both considered risky, involving high levels of uncertainty (Davila 2000) and difficult (Henri 2006) and contextually dependent (Hammad et al. 2013) tasks, the main theoretical idea was that controlled processes may identify the role of innovativeness's effect on growth. The reasoning behind this was that ideas could not be pursued blindly by wild-eyed risk takers (Wang and Tuttle 2014) but through sound behavioral controls (Simons 2013). Overall the model received strong support, particularly regarding the idea that current growth spurs future growth. The research is thus in line with the earlier theory (Audia et al. 2000; Bowen et al. 2010) suggesting that past experience will develop future growth. In support of forwardlooking research on growth rather than backward mechanisms determining growth (Bourne 2014; Chen 2008), this study may inspire new streams on how experiences and path dependence (i.e., earlier experience) determine future growth.

One assumption of this study is that personnel control is tied to organizational controls (i.e., individual in the organization) while action controls are tied to strategic management controls offering direction to selected goals (Colville 1981). While personnel control (H1) strongly reflecting freedom and independence of work received significant support, it was more perplexing that these gazelles seem to be less supportive of the idea that action control depends on innovativeness $(\mathrm{H} 2)$. We know that action control is less applicable to uncertainty and change, as well as requiring strong management skills (Haustein et al. 2014). Earlier research has also indicated that personnel control may work differently for different organizations (Kolk and Schokker 2016) and that the more complex an organization is, the more different and specific controls are needed (Haustein et al. 2014; Otley 1994). Gazelle companies in the 
early stages of becoming a larger organization with a complex structure may still be more strongly oriented by personnel control tied to operations and aligned with the corporate strategy, future mission, and goals. Furthermore, when diagnosing action control, we found no indirect support concerning either current or future growth. As action control conceptually breeds more follow-up and traditional control, rather than governance, it may also hamper the creative processes of innovativeness and growth. While personnel control also supported current and future growth indirectly, it can be concluded that controls need to be adjusted and balanced in a very sensitive manner.

The management (Kleine and Weißenberger 2014) and organizational control (Flamholtz et al. 1985) literature is based on a body of research that has captured the likelihood of attaining various goals (Anthony 1965), sometime conflicting (Bedford 2015; Mundy 2010), and specific performance measures reflected by specific metrics (Davila et al. 2004). The literature has further suggested that behavioral control implies a desired direction (Kihn 2007, 2008, 2010). While more research is indeed needed to follow up on these conceptualizations, the findings here signal some support for the notion that there is a hierarchical order of these concepts. The interpretation is that management action control dominates organizational control as they enter the model. Similarly, these controls are stable when current growth is perceived. The finding for action control seems to be robust for high-growth gazelle companies in Sweden.

Furthermore, management control has become widely applied in practice, wherein controllers, to name one category, follow up activities that have a financial, personnel, supplier, product, or other type of operational or strategic influence (Kleine and Weißenberger 2014). It is well known and established in the literature that innovation has a low level of correspondence to financial performance in the shorter term (e.g., Löfsten 2014). As innovative renewing processes involve uncertainty, this paper bases its argument on behavioral accounting, suggesting that uncertain output measures should be replaced with behavioral controls (Kihn 2007); others have claimed that it is more planned in nature. Furthermore, it is somewhat paradoxical to standardize metrics (i.e., controls) and nevertheless follow up these processes (i.e., direction). One idea concerning an innovation is its ecological nature of evolvement, which is only discouraged by strict controls. To this end, a management control system would theoretically constrain newness, creativity, and the development of new ideas (Frattini et al. 2006). These arguments may support the idea that management controls do not belong within the scope of innovation. However, many companies are bound to limited resources (Henri 2006). This subsequently means that the allocation of resources needs to be planned accordingly. If there is an excess of resources, which is true for many growth companies, then there is less need to plan and innovate (Pesämaa et al. 2013). Earlier studies on environmental munificence (Shea and Hamilton 2015) and innovativeness (Ven 1986) tended to show that munificent companies stick to their established practices instead of changing them, while less munificent companies are more willing to tackle situations that involve risk and uncertainty. Accordingly, this paper examined gazelle companies in Sweden with high-growth potential. The findings support the idea that such relatively small companies, with approximately ten employees, follow up and control significant innovative processes and their relationship with future growth. The fact that these companies also strongly base their future growth on their current growth means that their follow-up is based on learning from 
the current state. Gazelle companies seem to invest in innovative ideas not blindly but through accurate personnel control. In addition, it would be expected that high-growth gazelle companies, as relatively small companies with simple non-functional organizations, are more oriented towards strong personnel control. However, these findings rather support the suggestion that these are dominated by personnel control.

\section{Conclusion}

This paper presents several ideas to contribute to the management and organizational control literature on innovations. It focuses particularly on the intersection between innovativeness, control, and growth. Growth and innovativeness are assumed to be intertwined on the basis of the market responding to a company's offerings and thus considering these to be meaningful. While heuristic experiences of past trial-and-error mechanisms govern many behaviors, research has tended to overlook how current action may foster future action. This research suggests a theoretically rooted model that is empirically tested to shed light on how current growth affects ideas on future growth. The model further suggests that follow-up action and personnel controls are important to capture the true effects of innovativeness.

The extant research on management control and accounting has also focused on various aspects of innovation and control (e.g., Davila 2000; Henri 2006). Few studies on accounting have shown an interest in the literature on innovation and growth. Much of the prestige and knowledge within accounting is invested in general accounting, including contracting, tax, and international standard and equity appraisals. Traditions and the overall paradigm within this field may explain this dominance in the literature. In light of this lack of contribution from the literature on innovativeness, this paper suggests the need for further studies. Furthermore, given the fact that many companies, especially small and technology-oriented ones, which are extremely geared towards fast growth or innovative products, it is here believed that more studies are needed in this domain. The earlier literature has stressed not only that the correlation between innovation and performance is low but also that a vast amount of innovative products fail at a very high cost. Many companies may even risk their survival on innovative projects. On the other hand, much of the literature on innovation has concentrated on the creativity of ideas, in which it seems that awkward creative ideas, given their strength, should not be questioned. As the findings here support innovativeness as a controlled process, it may also inspire new contributions that identify various aspects of controlled innovative processes and the nature of these processes.

Furthermore, this paper adds to the literature by differentiating between various management control conceptualizations. The results find some support for the notion that personnel control following up plans dominates action control in the model.

Finally, generally gazelle companies are a relatively understudied area. The findings here suggest that gazelle companies not only base their future growth on their perceived current growth but that such growth is determined by accurate controls. This may further support the notion that high-growth companies, to a large extent, plan, execute, and follow up critical activities. Other companies can likely learn from high-growth 
practices, suggesting to them to employ clear goals, because what is measurable is more likely to be accomplished. Further studies are needed here.

\section{Limitations}

This study examined the influence of controls over innovativeness on current and future growth. However, some gazelle companies are at a very critical stage, and some companies may have limited ability to use formal controls in their relatively small organization. Future studies could include controls for robustness. A comparative study considering larger growing companies may shed important light on this issue. In addition, as the study was conducted in Sweden, more studies with a multi-country approach would broaden the perspective.

Second, many of the analyses are based on the originators and managers of the company. However, many of the concepts would have strong implications for employees and those being controlled and governed. This limitation is significant, and further studies are needed to explore the full impact of this theory on employees.

Third, this study only used established definitions with creative operationalizations. Further studies need to replicate and study the robustness of these measures with controls in other countries. In addition, further studies may use more strict operationalizations of the established scales to validate the paths in the regression.

Acknowledgements I sincerely like to thank and acknowledge Joakim Andersson and Niklas Engblom for access to data used in this article that were collected as part of their master's thesis.

Open Access This article is distributed under the terms of the Creative Commons Attribution 4.0 International License (http://creativecommons.org/licenses/by/4.0/), which permits unrestricted use, distribution, and reproduction in any medium, provided you give appropriate credit to the original author(s) and the source, provide a link to the Creative Commons license, and indicate if changes were made.

\section{References}

Abernethy, M. A., \& Brownell, P. (1999). The role of budgets in organizations facing strategic change: An exploratory study. Accounting, Organizations and Society, 24(3), 189-204.

Achtenhagen, L., Melander, A., Rosengren, A., \& Standoft, A. (2014). High-growth firms and the use of formalised planning and control systems. International Journal of Management and Decision Making, 13(3), 266-285.

Adams, S. J., Toole, H., \& Krause, P. (1993). Predictive performance evaluation measures: Field study of a multi-outlet business. Accounting and Business Research, 24(93), 3-10.

Alsharari, N. M., Dixon, R., \& Youssef, M. A. E. A. (2015). Management accounting change: Critical review and a new contextual framework. Journal of Accounting \& Organizational Change, 11(4), 476-502.

Anthony, R. N. (1965). Planning and control systems: A framework for analysis. Boston: Harvard Business School.

Armstrong, J. S., \& Overton, T. S. (1977). Estimating nonresponse bias in mail surveys. Journal of Marketing Research, 14(3), 396-402.

Audia, P., Locke, E., \& Smith, K. (2000). The paradox of success: An archival and a laboratory study of strategic persistence following radical environmental change. Academy of Management Journal, $43(5), 837-853$. 
Bai, G., Coronado, F., \& Krishnan, R. (2010). The role of performance measure noise in mediating the relation between task complexity and outsourcing. Journal of Management Accounting Research, 22(1), 75-102.

Balachandran, M. (1985). Behavioral accounting: An introduction. Behavioral \& Social Sciences Librarian, $4(2-3), 21-27$.

Bagozzi, R. P., \& Yi, Y. (2012). Specification, evaluation, and interpretation of structural equation models. Journal of the Academy of Marketing Science, 40(1), 8-34.

Bandura, A. (1997). Self-efficacy: The exercise of control. New York: Freeman.

Banker, R. D., \& Hughes, J. S. (1994). Product costing and pricing. Accounting Review, 69(3), 479-494.

Bedford, D. S. (2015). Management control systems across different modes of innovation: Implications for firm performance. Management Accounting Research, 28, 12-30.

Bedford, D. S., Malmi, T., \& Sandelin, M. (2016). Management control effectiveness and strategy: An empirical analysis of packages and systems. Accounting, Organizations and Society, 51, 12-28.

Bee, E. (2004). Small business vitality \& economic development. Economic Development Journal, 3(3), $7-15$.

Birch, D. G. (1979). The job generation process. Boston, MA: MIT Program on Neighborhood and Regional Change.

Bisbe, J., \& Malagueño, R. (2015). How control systems influence product innovation processes: Examining the role of entrepreneurial orientation. Accounting and Business Research, 45(3), 356-386.

Bourne, M. (2014). Managing through uncertainty. Management control and uncertainty (pp. 97-113). Basingstoke: Palgrave Macmillan.

Bowen, F. E., Rostami, M., \& Steel, P. (2010). Timing is everything: A meta-analysis of the relationships between organizational performance and innovation. Journal of Business Research, 63(11), 11791185 .

Broadbent, J., Gill, J., \& Laughlin, R. (2008). Identifying and controlling risk: The problem of uncertainty in the private finance initiative in the UK's National Health Service. Critical Perspectives on Accounting, 19(1), 40-78.

Burney, L. L., \& Widener, S. K. (2013). Behavioral work outcomes of a strategic performance measurement system-based incentive plan. Behavioral Research in Accounting, 25(2), 115-143.

Cavalluzzo, K. S., \& Ittner, C. D. (2004). Implementing performance measurement innovations: Evidence from government. Accounting, Organizations and Society, 29(3), 243-267.

Carayannis, E. G., \& Gonzalez, E. (2003). Creativity and innovation = Competitiveness? When, how, and why. In L. V. Shavinina (Ed.), The international handbook on innovation (pp. 587-606). Oxford: Elsevier Science.

Caves, R. E., \& Porter, M. E. (1977). From entry barriers to mobility barriers: Conjectural decisions and contrived deterrence to new competition. Quarterly Journal of Economics, 91(2), 241-261.

Chen, W. R. (2008). Determinants of firms' backward- and forward-looking R\&D search behavior. Organization Science, 19(4), 609-622.

Chenhall, R. H. (2003). Management control systems design within its organizational context: Findings from contingency-based research and directions for the future. Accounting, Organizations and Society, 28(2), 127-168.

Colville, I. (1981). Reconstructing "behavioural accounting”. Accounting, Organizations and Society, 6(2), 119-132.

Cosenz, F., \& Noto, L. (2015). Combining system dynamics modelling and management control systems to support strategic learning processes in SMEs: A dynamic performance management approach. Journal of Management Control, 26(2-3), 225-248.

Coy, J. M. (2013). Risk dynamics, growth options, and financial leverage. Journal of Finance, 64(2), 957983.

Curtis, E., \& Sweeney, B. (2016). Managing different types of innovation: Mutually reinforcing management control systems and the generation of dynamic tension. Accounting and Business Research, 1-31. doi:10.1080/00014788.2016.1255585.

Cyert, R. M., \& March, J. G. (1963). A behavioral theory of the firm (2nd ed.). Malden, MA: Blackwell Publishers.

Davila, A., \& Foster, G. (2005). Management accounting systems adoption decisions: Evidence and performance implications from early-stage/startup companies. Accounting Review, 80(4), 1039-1068.

Davila, T. (2000). An empirical study on the drivers of management control systems' design in new product development. Accounting, Organizations and Society, 25(4), 383-409. 
Davila, T., Epstein, M. J., \& Matusik, F. (2004). Innovation strategy and the use of performance measures. Advances in Management Accounting, 13, 27-58.

De Harlez, Y., \& Malagueño, R. (2015). Examining the joint effects of strategic priorities, use of management control systems, and personal background on hospital performance. Management Accounting Research, 30, 2-17.

Eccles, R. G., \& Pyburn, P. J. (1992). Creating a comprehensive system to measure performance. Management Accounting, 74(4), 41-44.

Epstein, M. J. (2016). Breakthrough innovation: The critical role of management control systems. Performance measurement and management control: Contemporary issues (pp. 3-16). Bingley: Emerald Group Publishing Limited.

Flamholtz, E. G., Das, T. K., \& Tsui, A. S. (1985). Toward an integrative framework of organizational control. Accounting, Organizations and Society, 10(1), 35-50.

Frattini, F., Lazzarotti, V., \& Manzini, R. (2006). Towards a system of performance measures for research activities: NiKem research case study. International Journal of Innovation Management, 10(4), 425454.

Gaba, V., \& Joseph, J. (2013). Corporate structure and performance feedback: Aspirations and adaptation in M-form firms. Organization Science, 24, 1102-1119.

Gardner, D. M., Johnson, F., Lee, M., \& Wilkinson, I. (2000). A contingency approach to marketing high technology products. European Journal of Marketing, 34(9/10), 1053-1077.

Geroski, P. A., Machin, S. J., \& Walters, C. F. (1997). Corporate growth and profitability. Journal of Industrial Economics, 45(2), 171-189.

Ghalayini, A. M., \& Noble, J. S. (1996). The changing basis of performance measurement. International Journal of Operations \& Production Management, 16(8), 63-80.

Girardi, A., Soutar, G. N., \& Ward, S. (2005). The validation of a use innovativeness scale. European Journal of Innovation Management, 8(4), 471-481.

Greve, H. R. (2003a). Organizational learning from performance feedback. Cambridge: Cambridge University Press.

Greve, H. R. (2003b). A behavioral theory of R\&D expenditures and innovations: Evidence from shipbuilding. Academy of Management Journal, 46, 682-702.

Groesser, S. N., \& Jovy, N. (2016). Business model analysis using computational modeling: A strategy tool for exploration and decision-making. Journal of Management Control, 27(1), 61-88.

Guenther, T. W. (2013). Conceptualisations of "controlling" in German-speaking countries: Analysis and comparison with Anglo-American management control frameworks. Journal of Management Control, 23(4), 269-290.

Gurd, B., \& Helliar, C. (2016). Balancing risk and innovation: The role of institutional leadership. British Accounting Review (in press).

Hair, J. F., Black, B., Babin, B., \& Anderson, R. E. (2010). Multivariate data analysis (7th ed.). Upper Saddle Creek, NJ: Prentice-Hall.

Hammad, A. S., Jusoh, R., \& Ghozali, I. (2013). Decentralization, perceived environmental uncertainty, managerial performance and management accounting system information in Egyptian hospitals. International Journal of Accounting and Information Management, 21(4), 314-330.

Haustein, E., Luther, R., \& Schuster, P. (2014). Management control systems in innovation companies: A literature based framework. Journal of Management Control, 24(4), 343-382.

Heinicke, A., Guenther, T. W., \& Widener, S. K. (2016). An examination of the relationship between the extent of a flexible culture and the levers of control system: The key role of beliefs control. Management Accounting Research, 33, 25-41.

Henrekson, M., \& Johansson, D. (2010). Gazelles as job creators: A survey and interpretation of the evidence. Small Business Economics, 35(2), 227-244.

Henri, J. F. (2006). Management control systems and strategy: A resource-based perspective. Accounting, Organizations and Society, 31(6), 529-558.

Helsen, Z., Lybaert, N., Steijvers, T., Orens, R., \& Dekker, J. (2016). Management control systems in family firms: A review of the literature and directions for the future. Journal of Economic Surveys (in press).

Hölzl, W. (2009). Is the R\&D behaviour of fast-growing SMEs different? Evidence from CIS III data for 16 countries. Small Business Economics, 33(1), 59-75.

Huang, X., Xu, E., Chiu, W., Lam, C., \& Farh, J. L. (2015). When authoritarian leaders outperform transformational leaders: Firm performance in a harsh economic environment. Academy of Management Discoveries, 1(2), 180-200. 
Hunt, S. C. (1995). A review and synthesis of research in performance evaluation in public accounting. Journal of Accounting Literature, 14, 107-139.

Hyatt, T. A., \& Taylor, M. H. (2008). The effects of incomplete personal capability knowledge and overconfidence on employment contract selection. Behavioral Research in Accounting, 20(2), 37-53.

Ijiri, Y. (1975). Theory of accounting measurement (No. 10). Sarasota: American Accounting Association.

Ittner, C. D., \& Larcker, D. F. (1998). Innovations in performance measurement: Trends and research implications. Journal of Management Accounting Research, 10, 205-238.

Ittner, C. D., \& Larcker, D. F. (2003). Coming up short on nonfinancial performance measurement. Harvard Business Review, 81(11), 88-95.

Jänkälä, S., \& Silvola, H. (2012). Lagging effects of the use of activity-based costing on the financial performance of small firms. Journal of Small Business Management, 50(3), 498-523.

Janssen, S., Möller, K., \& Schläfke, M. (2011). Using performance measures conceptually in innovation control. Journal of Management Control, 22(1), 107-128.

Katsikea, E. S., Papavassiliou, N., Theodosiou, M., \& Morgan, R. E. (2005). Export market expansion strategies of direct-selling small and medium-sized firms: Implications for export sales management activities. Journal of International Marketing, 13(2), 57-92.

Katsikea, E., Theodosiou, M., \& Morgan, R. E. (2015). Why people quit: Explaining employee turnover intentions among export sales managers. International Business Review, 24(3), 367-379.

Kennedy, T., \& Affleck-Graves, J. (2001). The impact of activity-based costing techniques on firm performance. Journal of Management Accounting Research, 13, 19-45.

Kihn, L.-A. (2007). Financial consequences in foreign subsidiary management performance evaluations. European Management Review, 16(3), 1-32.

Kihn, L.-A. (2008). The determinants of multiple forms of controls in foreign subsidiary manager evaluations. International Journal of Accounting, Auditing and Performance Evaluation, 5(2), 157-182.

Kihn, L.-A. (2010). An empirical investigation of the principal top management styles in the emphasis of multiple forms of controls. International Journal of Accounting, Auditing and Performance Evaluation, 6(1), 108-127.

Kim, J., Haleblian, J., \& Finkelstein, S. (2011). When firms are desperate to grow via acquisition: The effect of growth patterns and acquisition experience on acquisition premiums. Administrative Science Quarterly, 56(1), 26-60.

Kleine, C., \& Weißenberger, B. E. (2014). Leadership impact on organizational commitment: The mediating role of management control systems choice. Journal of Management Control, 24(3), 241-266.

Kotlar, J., Fang, H., De Massis, A., \& Frattini, F. (2014). Profitability goals, control goals, and the R\&D investment decisions of family and nonfamily firms. Journal of Product Innovation Management, 31(6), 1128-1145.

Kraus, K., Kennergren, C., \& von Unge, A. (2016). The interplay between ideological control and formal management control systems - A case study of a non-governmental organisation. Accounting, Organizations and Society. doi:10.1016/j.aos.2016.02.001.

Laitinen, E. K. (2011). Management accounting in pricing decisions. In M. Abdel-Kader (Ed.), Review of management accounting research. Basingstoke: Palgrave Macmillan.

Laitinen, E. K. (2014). Influence of cost accounting change on performance of manufacturing firms. Advances in Accounting, 30(1), 230-240.

Langfield-Smith, K. (2006). A review of quantitative research in management control systems and strategy. Handbooks of Management Accounting Research, 2, 753-783.

Lau, C. M. (2015). The effects of nonfinancial performance measures on role clarity, procedural fairness and managerial performance. Pacific Accounting Review, 27(2), 142-165.

Lavia López, O., \& Hiebl, M. R. (2014). Management accounting in small and medium-sized enterprises: Current knowledge and avenues for further research. Journal of Management Accounting Research, 27(1), 81-119.

Löfsten, H. (2014). Product innovation processes and the trade-off between product innovation performance and business performance. European Journal of Innovation Management, 17(1), 61-84.

Lopez-Garcia, P., \& Puente, S. (2012). What makes a high-growth firm? A dynamic probit analysis using Spanish firm-level data. Small Business Economics, 39(4), 1029-1041.

Lounsbury, M., \& Beckman, C. M. (2015). Celebrating organization theory. Journal of Management Studies, 52(2), 288-308.

Luft, J. L., \& Shields, M. D. (2001). Why does fixation persist? Experimental evidence on the judgment performance effects of expensing intangibles. Accounting Review, 76(4), 561-587. 
Mahama, H. (2006). Management control systems, cooperation and performance in strategic supply relationships: A survey in the mines. Management Accounting Research, 17(3), 315-339.

Maiga, A. S., \& Jacobs, F. A. (2008). Extent of ABC use and its consequences. Contemporary Accounting Research, 25(2), 533-566.

Malmi, T., \& Brown, D. A. (2008). Management control systems as a package: Opportunities, challenges and research directions. Management Accounting Research, 19(4), 287-300.

Martin-Rios, C. (2015). Innovative management control systems in knowledge work: A middle manager perspective. Journal of Management Control, 27(2), 181-204.

Matsuo, M. (2009). The influence of sales management control on innovativeness of sales departments. Journal of Personal Selling \& Sales Management, 29(4), 321-331.

McGee, J. E., Dowling, M. J., \& Megginson, W. L. (1995). Cooperative strategy and new venture performance: The role of business strategy and management experience. Strategic Management Journal, 16(7), 565-580.

McKelvie, A., \& Wiklund, J. (2010). Advancing firm growth research: A focus on growth mode instead of growth rate. Entrepreneurship Theory and Practice, 34(2), 261-288.

Merchant, K. A., \& Van der Stede, W. A. (2007). Management control systems: Performance measurement, evaluation and incentives. New York: Pearson Education.

Michael, S. C. (2003). First mover advantage through franchising. Journal of Business Venturing, 18(1), 61-80.

Miller, D., \& Chen, M. J. (1994). Sources and consequences of competitive inertia: A study of the US airline industry. Administrative Science Quarterly, 39(1), 1-23.

Miller, T. C., \& Cockrell, R. C. (2015). Discussion of: Workplace culture mediates performance appraisal effectiveness and employee outcomes: A study in a retail setting. Journal of Management Accounting Research, 27(2), 35-38.

Morris, M. H., Allen, J., Schindehutte, M., \& Avila, R. (2006). Balanced management control systems as a mechanism for achieving corporate entrepreneurship. Journal of Managerial Issues, 18(4), 468-493.

Mundy, J. (2010). Creating dynamic tensions through a balanced use of management control systems. Accounting, Organizations and Society, 35(5), 499-523.

Othman, R., \& Said, J. (2007). Enhancing control through participation: Issues of conflicts in public sector organizations. Journal of Financial Reporting and Accounting, 5(1), 71-86.

Otley, D. (1994). Management control in contemporary organizations: Towards a wider framework. Management Accounting Research, 5(3), 289-299.

Ouchi, W. G. (1977). The relationship between organizational structure and organizational control. Administrative Science Quarterly, 22(1), 95-113.

Palacios Fenech, J., \& Tellis, G. J. (2015). The dive and disruption of successful current products: Measures, global patterns, and predictive model. Journal of Product Innovation Management, 33(1), 53-68.

Parida, V., Pesämaa, O., Wincent, J., \& Westerberg, M. (2016). Network capability, innovativeness, and performance: A multidimensional extension for entrepreneurship. Entrepreneurship \& Regional Development, 1-22. doi:10.1080/08985626.2016.1255434.

Pesämaa, O., Shoham, A., Wincent, J., \& Ruvio, A. A. (2013). How a learning orientation affects drivers of innovativeness and performance in service delivery. Journal of Engineering and Technology Management, 30(2), 169-187.

Rosenbusch, N., Brinckmann, J., \& Bausch, A. (2011). Is innovation always beneficial? A meta-analysis of the relationship between innovation and performance in SMEs. Journal of Business Venturing, 26(4), $441-457$.

Ryzhkova, N., \& Pesämaa, O. (2015). Absorptive capacity, collaboration with customers and innovation performance of gazelle companies in knowledge-intensive industries. International Journal of Innovation Management, 19(5), 1-27.

Sandelin, M. (2008). Operation of management control practices as a package: A case study on control system variety in a growth firm context. Management Accounting Research, 19(4), 324-343.

Shea, M., \& Hamilton, R. D. (2015). Who determines how nonprofits confront uncertainty? Nonprofit Management and Leadership, 25(4), 383-401.

Shinkle, G. A. (2012). Organizational aspirations, reference points, and goals building on the past and aiming for the future. Journal of Management, 38(1), 415-455.

Simons, R. (1987). Accounting control systems and business strategy: An empirical analysis. Accounting, Organizations and Society, 12(4), 357-374. 
Simons, R. (1994). How new top managers use control systems as levers of strategic renewal. Strategic Management Journal, 15(3), 169-189.

Simons, R. (2013). Levers of control: How managers use innovative control systems to drive strategic renewal. Harvard: Harvard Business Press.

Soin, K., \& Collier, P. (2013). Risk and risk management in management accounting and control. Management Accounting Research, 24(2), 82-87.

Speklé, R. F., \& Verbeeten, F. H. (2014). The use of performance measurement systems in the public sector: Effects on performance. Management Accounting Research, 25(2), 131-146.

St-Jean, E., Julien, P. A., \& Audet, J. (2008). Factors associated with growth changes in "gazelles". Journal of Enterprising Culture, 16(2), 161-188.

Strauß, E., \& Zecher, C. (2013). Management control systems: A review. Journal of Management Control, 23(4), 233-268.

Tell, J. (2012). Managerial strategies in small, fast-growing manufacturing firms. Journal of Management Development, 31(7), 700-710.

Tessier, S., \& Otley, D. (2012). A conceptual development of Simons' Levers of Control framework. Management Accounting Research, 23(3), 171-185.

Van de Ven, A. H. (1986). Central problems in the management of innovation. Management Science, 32(5), 590-607.

Van de Ven, A. H., \& Polley, D. (1992). Learning while innovating. Organization Science, 3(1), 92-116.

Van der Kolk, B., \& Schokker, T. (2016). Strategy implementation through hierarchical couplings in a management control package: An explorative case study. Journal of Management Control, 27(2-3), $129-154$.

Venkatraman, N. U., \& Ramanujam, V. (1987). Measurement of business economic performance: An examination of method convergence. Journal of Management, 13(1), 109-122.

Virtanen, T., Tuomaala, M., \& Pentti, E. (2013). Energy efficiency complexities: A technical and managerial investigation. Management Accounting Research, 24(4), 401-416.

Wang, L., \& Tuttle, B. (2014). Using corporate social responsibility performance to evaluate financial disclosure credibility. Accounting and Business Research, 44(5), 523-544.

Weber, J. (2011). The development of controller tasks: Explaining the nature of controllership and its changes. Journal of Management Control, 22(1), 25-46.

Werker, C. (2003). Innovation, market performance, and competition: Lessons from a product life cycle model. Technovation, 23(4), 281-290.

Widener, S. K. (2007). An empirical analysis of the levers of control framework. Accounting, Organizations and Society, 32(7), 757-788.

Widener, S. (2014). Researching the human side of management control: Using survey-based methods. Management control and uncertainty (pp. 69-82). Basingstoke: Palgrave Macmillan.

Wold, H. (1989). Theoretical empiricism: A general rationale for scientific model-building. New York: Paragon House.

Zane, L. J. (2011). How social capital and firm knowledge influence the acquisition of resources in technology based new ventures. Doctoral dissertation, Drexel University. 